\title{
Asymmetric Reactions of China's Stock Market to Short-term Interest Rates
}

\author{
Fang Fang ${ }^{1}$, Weijia Dong ${ }^{2} \&$ Xin $\mathrm{Lv}^{3}$ \\ ${ }^{1}$ Business School, Beijing Normal University, Beijing, China \\ ${ }^{2}$ Graduate School of Economics, Nagoya University, Nagoya, Japan \\ ${ }^{3}$ School of Management and Economics, Center for Energy \& Environmental Policy Research, Beijing Institute \\ of Technology, Beijing, China
}

Correspondence: Xin Lv, School of Management and Economics, Beijing Institute of Technology, Beijing, China. E-mail: lvxin2311@bit.edu.cn

Received: Feburary 17, 2016

Accepted: March 16, 2016

Online Published: April 25, 2016

doi:10.5539/ijef.v8n5p260

URL: http://dx.doi.org/10.5539/ijef.v8n5p260

\begin{abstract}
This paper investigates how China's stock market reacts to short-term interest rates, as represented by the Shanghai Interbank Offered Rate (Shibor). We adopt the Markov Regime Switching model to divide China's stock market into Medium, Bull and Bear market; and then examine how Shibor influences market returns and risk in different market regimes. We find that short-term interest rates have a significant negative effect on stock returns in Medium and Bull market, but could not affect stock returns in Bear market. In addition, different maturities of Shibor have different effects on stock returns. Furthermore, we find that the short-term interest rates have a negative effect on market risk in Bull market, but a positive effect in Bear market. Our findings show that China's market is quite peculiar and distinctive from the U.S. market or other developed countries' markets in many ways.
\end{abstract}

Keywords: short-term interest rate, stock returns, market risk, Markov Regime Switching model, GJR-GARCH model

\section{Introduction}

The short-term interest rate as a benchmark interest rate is a leading indicator of the macro-economy and the stock market. Investors always predict the stock market based on the current trend of the short-term interest rate. Therefore, abundant research explains the relationship between the (short-term) interest rate and the stock market. Campbell and Shiller (1988) proves that the equilibrium share price is determined by the discounted value of the expected cash flows. Furthermore, based on the dividend discount model, Campbell and Ammer (1993) decomposes the variance of unexpected excess returns into three factors: news about future dividends, news about future interest rates, and news about future excess returns. In addition, they indicate that interest rate shocks should affect stock prices and may affect the variance of stock returns.

Recently, Henry (2009) summarizes that changes in the interest rate may affect stock prices through three alternative channels. The first possible channel is the effect on the funding costs of a leveraged firm. Generally, interest rate changes will change the cost of debt of a leveraged firm, and thus, firm profits, which may cause both division within a firm and stock price decreases. Second, the opportunity cost of equity investments is modified by interest rate changes, which also affects stock prices. Third, the real economy in the short to medium term is affected by such changes, which alters a firm's expected future cash flows. Therefore, changes in the interest rate theoretically affect stock prices.

Substantial empirical evidences also exist to support the notion that interest rate changes definitely affect the stock market. Thorbecke (1997) finds that an expansionary monetary policy increases ex post stock returns. In addition, Rigobon and Sack (2003) reports that the monetary policy responds to the stock market; and Bernanke and Kuttner (2005) concludes that interest rate shocks negatively affect U.S. stock market returns. Indeed, Basistha and Kurov (2008) and Kurov (2010) provide empirical evidence supporting that the stock market reacts negatively to changes in interest rates. Furthermore, Chen (2007) and Henry (2009) note that short-term interest rates have asymmetric effects on the stock returns in different market regimes. Gagnon and Gimet (2013) argues 
lowering interest rates lead to a short-term decrease in stock market volatility. Gospondinov and Jamali (2015) shows stock market volatility is affected by changes in monetary policy.

However, all these studies focus on the U.S. market or developed countries' markets; only few researches focused on whether and how short-term interest rates affect the Chinese stock market. Recently, Yao et al. (2013) finds monetary policies have little immediate effect on asset prices in China. Liu et al. (2014) proves that although monetary policy is still shown to be ineffective, it reacts actively to asset prices. $\mathrm{Li}$ (2015) argues that the monetary policy shocks, especially the sentiment shocks, led to much larger fluctuation of stock prices. These literatures indicate that the relationship between short-term interest rates and the stock market in China is quite different from developed counties. Intuitively, the difference may come from two points: first, although the Chinese stock market has been developing for some time, it is less developed than other advanced stock exchanges in the world due to its regulations and imperfections. Second, in addition to the differences in its stock markets, China's monetary system also works differently from the systems of other advanced economies. Even now, the People's Bank of China (China's central bank) directly controls deposit and loan interest rates and commercial-bank-credit amounts through administrative orders. Since both China's stock market and its mechanism for making interest rate decisions are different from developed countries, it is doubtful whether the experience of developed countries can apply directly to China, which motivates us to investigate this world's largest emerging stock market.

This paper's contributions mainly come from the following two aspects. The first innovation explains a new type of asymmetric effects of short-term interest rates on market return. Following Lv (2012) and Lv et al. (2015), we adopt the Markov Regime Switching model to divide China's market into three regimes: Medium market (with a medium mean and the lowest variance), Bull market (with the highest mean and a medium variance) and Bear market (with the lowest mean and the highest variance). Then based on this unique market structure, we show that the short-term interest rates have a significant negative effect on stock market returns in Medium and Bull market, but no regular effect in Bear market. In addition, we also show Shibor with short maturities have larger effects on stock returns than Shibor with long maturities.

Second, we also examine the effects of the short-term interest rate on the market risk, which is usually measured by variance, in all three market regimes. We find that the short-term interest rates cannot affect market risk in Medium market, but have a negative effect on market risk in Bull market, and a positive effect in Bear market. These results indicate that monetary policies affect stock market returns and risk separately.

The rest of this paper is structured as follows: Section 2 presents a theoretical background and characteristics of China's stock market and short-term interest rates. Section 3 specifies the basic Markov Regime Switching model and the GJR- GARCH model, and also describes the data used in this paper. In addition, Section 4 shows the empirical results and the robustness check. Finally, the conclusions are offered in Section 5.

\section{Introduction to China's Stock Market and Monetary Policy}

\subsection{China's Stock Market}

Although China has two stock exchanges, generally investors and financial institutions pay more attention to the Shanghai Stock Exchange, which was established on November 26, 1990. After over two decades of development, nearly 1100 companies are now listed there, and the total market value of the two stock exchange markets has reached 23 trillion RMB. Figure 1 shows recent trends in the SSE composite index and China's GDP growth rate. The SSE indices are calculated using a Paasche weighted composite price index formula, which implies that the calculation of the index is based on a base period on a specific base day. The base day for the SSE Composite Index is December 19, 1990, and the capitalization of the base period is the total market capitalization of all stocks on that day. The base value is 100. A comparison of the SSE composite index and the GDP growth rate shows that China's stock market is not a good match with the real economy, which is an important characteristic of China's stock market. 

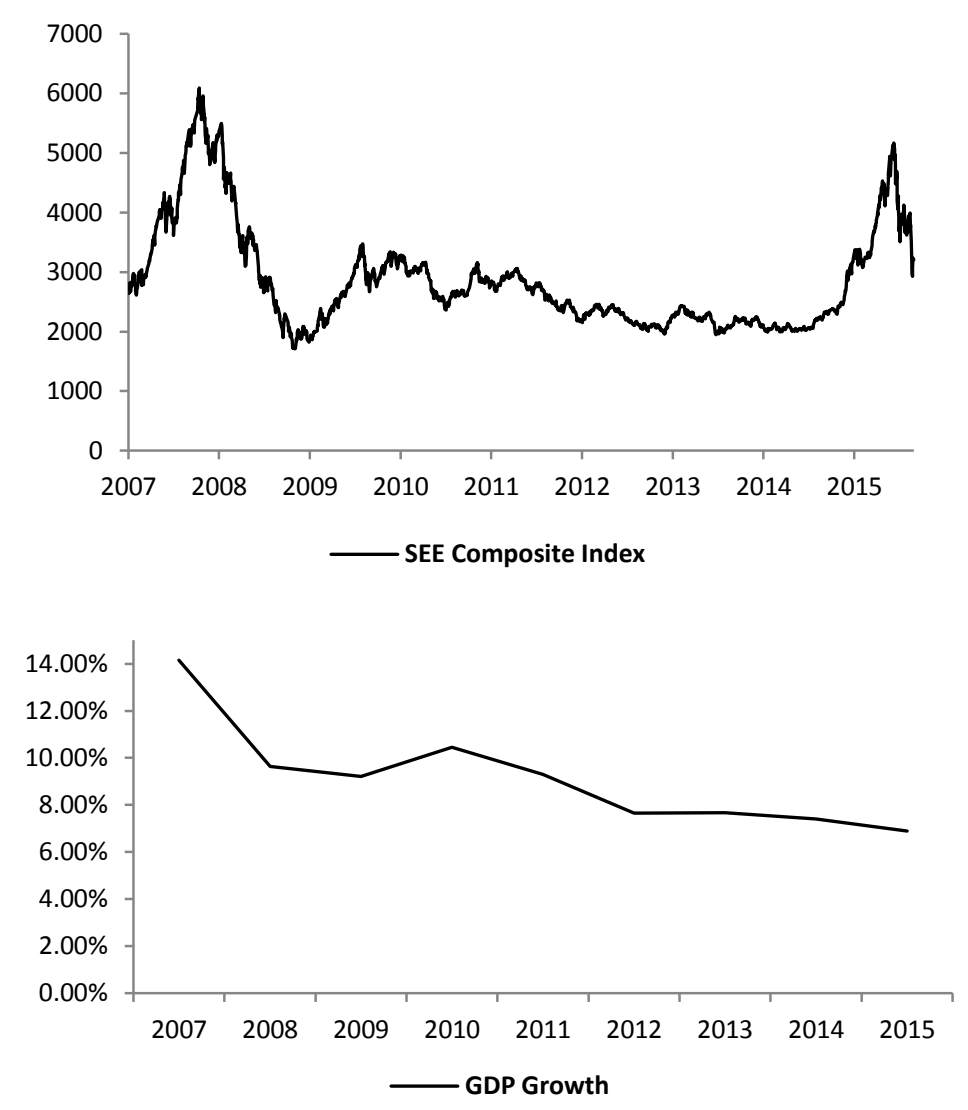

Figure 1. SSE composite index and GDP growth

\subsection{China's Short-Term Interest Rates}

China's base interest rates are regulated by the People's Bank of China (PBC). In addition to the benchmark rates such as loan rates to financial institutions, official rates on deposits and financial institution loans are controlled by the PBC. Therefore, the base short-term interest rates in China are considered official interest rates that have been determined by the People's Bank of China (Fan et al., 2011). According to PBC's report, these short-term official deposit and loan rates have been changed nearly 40 times during the past few decades. However, because these official rates are discrete data points, we cannot use them to estimate the GARCH group models, which generally call for continuous data. Therefore, we consider adopting the Shanghai Interbank Offered Rate (Shibor) as a short-term interest rate substitute for the official rates. Although the benchmark rates are determined by the PBC, Chinese government seeks to set up a system in which the benchmark rates are determined by the monetary market. Shibor is an experiment for this financial reform. Since 2007, the sixteen largest banks in China have reported their short-term interest rates, and the average of these short-term interest rates is called the Shibor. The maturities of the Shibor are overnight, one week, two weeks, one month, three months, six months, nine months, and one year.

Although Shibor is determined by the monetary market, to some extent it shows a very similar trend to the official rate. Therefore, it is reasonable for us to choose the Shibor as the short-term interest rate to match the daily stock index data. Figure 2 shows that the one-year Shibor has a similar volatility direction as the one-year deposit rate and the one-year loan rate, however, the fluctuation of one-week Shibor is much greater than one-year Shibor. 


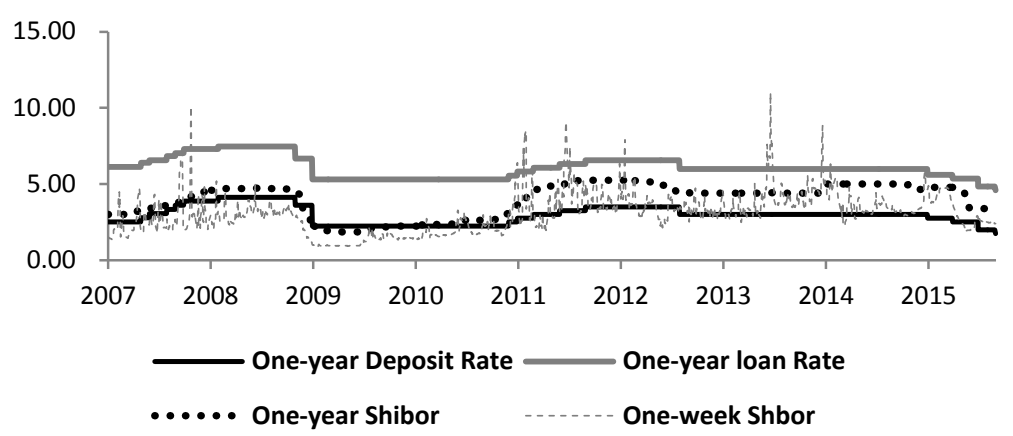

Figure 2. One-year deposit rate, one-year loan rate, one-year shibor and one-week shibor

\section{Empirical Models and the Data}

This paper first applies Markov Regime Switching model to divide China's stock market into three regimes (Bull, Medium and Bear markets), and then uses GJR-GARCH model to investigate the asymmetric effects of short-term interest rates on stock market return and risk.

\subsection{The Markov Regime Switching Model}

The Markov Regime Switching model, which is presented by Hamilton (1989), is widely used to divide stock market regimes. Following Lv (2012) and Lv et al. (2015), we divide China's stock market into three regimes on the basis of its stock returns. The Markov Regime Switching model without conditional heteroskedastic variance may be specified as follows:

$$
R_{t}=\mu_{S_{t}}+\varepsilon_{t}, \quad \varepsilon_{t} \sim \text { i.i.d. } t\left(0, \sigma_{S_{t}}^{2}, K_{S_{t}}\right)
$$

where $R_{t}=\left(Q_{t}-Q_{t-1}\right) / Q_{t-1}$ represents the returns of the Shanghai stock market, calculated on the basis of Qt, the composite index of the Shanghai Stock Exchange; $S_{t}$ is a state variable that may assume values of 1, 2 or 3 to indicate Medium, Bull or Bear markets, respectively; $\mu_{S_{t}}$ and $\sigma_{S_{t}}^{2}$ are the state-dependent mean and variance; and $\varepsilon_{\mathrm{t}}$ is an error component that follows Student's $\mathrm{t}$ distribution. When it comes to divide the market into three regimes, we not only compare the smoothed probability of each regime $\pi_{i t}(i=1,2,3)$, but also their 10-day moving average values $\overline{\pi_{1 \mathrm{t}}}=\sum_{t=4}^{\mathrm{t}+5} \pi_{\mathrm{it}} / 10(\mathrm{i}=1,2,3)$, to avoid the "sudden shock point" between different market regimes.

\subsection{The GJR-GARCH Model}

When testing how a stock market reacts to news or events, it is necessary to consider two types of reactions: one is stock market returns and the other is stock market risk (which is measured by the variance). Thus, we apply one type of the GARCH group model, which is widely used in finance to test the relationships among endogenous variables, exogenous variables, stock returns, and stock volatility.

Bollerslev (1986) modified Engle (1982)'s original ARCH model into a more generalized GARCH model that can be described as follows:

$$
\begin{gathered}
R_{t}=\mu_{t}+\xi_{t}, \quad \xi_{t} \sim \text { i.i.d.N }(0,1) \\
\sigma_{t}^{2}=\omega+\sum_{i=1}^{q} \beta_{i} \sigma_{t-i}^{2}+\sum_{j=1}^{p} \alpha_{j} \xi_{t-j}^{2}
\end{gathered}
$$

However, it has many drawbacks, which mainly comes from the problem that it may fail to capture the asymmetry effect of the error term for the variance. Glosten et al. (1989) and Zakoian (1990) defined GJR-GARCH (which is sometimes named TGARCH), and it is proved to be one of the best in capturing the character of asymmetry effect and estimating the parameters (Engle \& Ng, 1993). The GJR-GARCH $(1,1)$ model can be described as:

$$
\begin{gathered}
R_{t}=\mu_{t}+\xi_{t}, \quad \xi_{t} \sim \text { i.i.d.N }(0,1) \\
\sigma_{t}^{2}=\omega+\eta \xi_{t-1}{ }^{2}+\gamma S_{t-1}{ }^{-} \xi_{t-1}{ }^{2}+\theta \sigma_{t-1} \\
S_{t}^{-}=1 \text { if } \xi_{t}<0, \quad S_{t}{ }^{-}=0 \text { otherwise. }
\end{gathered}
$$

In order to test how the monetary policy affects the stock market, we modify the above model as follows. 


$$
\begin{gathered}
R_{t}=\mu_{t}+\beta_{1} \Delta r_{n, t-1}+\beta_{2} x_{\text {bull }} \Delta r_{n, t-1}+\beta_{3} x_{\text {bear }} \Delta r_{n, t-1}+\beta_{4} \sigma_{t}^{2}+\xi_{t} \\
\xi_{t} \sim \text { i.i.d. } t\left(0, \sigma_{S_{t}}^{2}, K_{S_{t}}\right) \\
\sigma_{t}^{2}=\omega+\eta \xi_{t-1}{ }^{2}+\gamma S_{t-1}{ }^{-} \xi_{t-1}{ }^{2}+\theta \sigma_{t-1}+\lambda_{1} \Delta r_{n, t-1}+\lambda_{2} x_{\text {bull }} \Delta r_{n, t-1}+\lambda_{3} x_{b e a r} \Delta r_{n, t-1} \\
S_{t}{ }^{-}=1 \text { if } \xi_{t}<0, \quad S_{t}{ }^{-}=0, \text { otherwise }
\end{gathered}
$$

where $r_{n, t}$ represents the Shibor rate, $\Delta r_{n, t-1}=r_{n, t-1}-r_{n, t-2}$ represents the change of Shibor, and the subscript $n$ indicates different maturities of Shibor, $\mathrm{n}=1 \mathrm{D}, 1 \mathrm{~W}, 2 \mathrm{~W}, 1 \mathrm{M}, 3 \mathrm{M}, 6 \mathrm{M}, 9 \mathrm{M}, 1 \mathrm{Y}$, which represent Shibor with overnight, one-week, two-week, one-month, three-month, six-month, nine-month, and one-year maturity, respectively.

In the above modified models, the first modification was performed on the assumption for $\xi_{\mathrm{t}}$. We assume that $\xi_{\mathrm{t}}$ follows Student's t distribution that is consistent with the Markov Regime Switching model. The second change is to add the monetary policy variable $\Delta \mathrm{r}_{\mathrm{n}, \mathrm{t}-1}$ and the market regime dummy variables $\mathrm{x}_{\text {bull }}$ and $\mathrm{x}_{\mathrm{bear}}$ into each model. Based on this modified GJR-GARCH model, the effects of the short-term interest rates on the stock returns are depicted by the coefficients $\beta_{1}, \beta_{1}+\beta_{2}$ and $\beta_{1}+\beta_{3}$ in Medium, Bull and Bear Market, respectively. In addition, the coefficients $\lambda_{1}, \lambda_{1}+\lambda_{2}$ and $\lambda_{1}+\lambda_{3}$ measure the reactions of the stock market risk (which is measured by the variance) to the monetary policy in Medium, Bull and Bear Market, respectively. Furthermore, other estimators describe some characteristics of heteroskedastic models.

\subsection{Data}

The full sample period contains the 2107 days from 4th January, 2007 to 31st August, 2015. The SSE composite index and the Shibor data are collected from the Wind Information Database.

\section{Results}

\subsection{The Unit Root Test}

In the preliminary analysis, the stationarity of the variables is tested. Table 1 reports the test statistics of the augmented Dickey-Fuller (1979) test and the Phillips-Perron (1988) test, where the null hypothesis is that the series have a unit root. We reject the null hypotheses for both of the variables $R_{t}$ and $\Delta r_{n, t}$.

Table 1. Unit root test

\begin{tabular}{cll}
\hline & ADF Test & PP Test \\
\hline $\mathrm{R}_{\mathrm{t}}$ & $-46.0304 * * *$ & $-46.0534 * * *$ \\
$\Delta \mathrm{r}_{1 \mathrm{D}, \mathrm{t}}$ & $-17.8640^{* * *}$ & $-54.3578 * * *$ \\
$\Delta \mathrm{r}_{1 \mathrm{~W}, \mathrm{t}}$ & $-19.1197 * * *$ & $-51.5103 * * *$ \\
$\Delta \mathrm{r}_{2 \mathrm{~W}, \mathrm{t}}$ & $-20.0960^{* * *}$ & $-59.0559 * * *$ \\
$\Delta \mathrm{r}_{1 \mathrm{M}, \mathrm{t}}$ & $-14.4022^{* * *}$ & $-37.1695 * * *$ \\
$\Delta \mathrm{r}_{3 \mathrm{M}, \mathrm{t}}$ & $-13.8982^{* * *}$ & $-28.6250^{* * *}$ \\
$\Delta \mathrm{r}_{6 \mathrm{M}, \mathrm{t}}$ & $-9.4624^{* * *}$ & $-42.7860^{* * *}$ \\
$\Delta \mathrm{r}_{9 \mathrm{M}, \mathrm{t}}$ & $-10.4868^{* * *}$ & $-44.0137 * * *$ \\
$\Delta \mathrm{r}_{1 \mathrm{Y}, \mathrm{t}}$ & $-10.6727 * * *$ & $-44.4637 * * *$ \\
\hline
\end{tabular}

Note. $* * *$ indicate $10 \%, 5 \%$ and $1 \%$ levels of significance.

\subsection{Markov Regime Switching}

To estimate the Markov Regime Switching model, we first consider the problem of autoregressive (AR) order. Chen (2007) and Henry (2009) chose to have no AR lag in stock returns. We follow their methodology to choose no AR lag in $R_{t}$ based on the calculation of the Akaike information criterion (AIC). Estimations of the Markov Switching Model produce the smoothed transition probabilities for Bull, Medium and Bear markets. Figure 3 depicts the smoothed probabilities $\pi_{\mathrm{it}}$ of three market regimes for every date of the sample period. The 10-day moving average values of smoothed probabilities $\overline{\pi_{\mathrm{tt}}}$ is very similar to $\pi_{\mathrm{it}}$. 

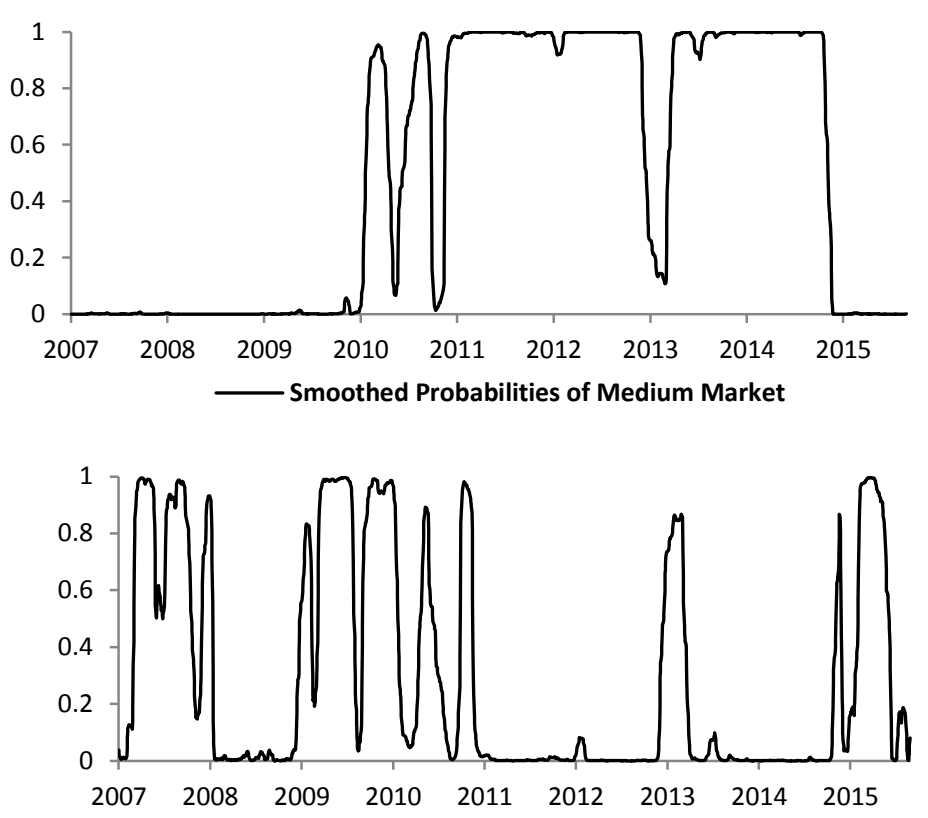

Smoothed Probabilities of Bull Market

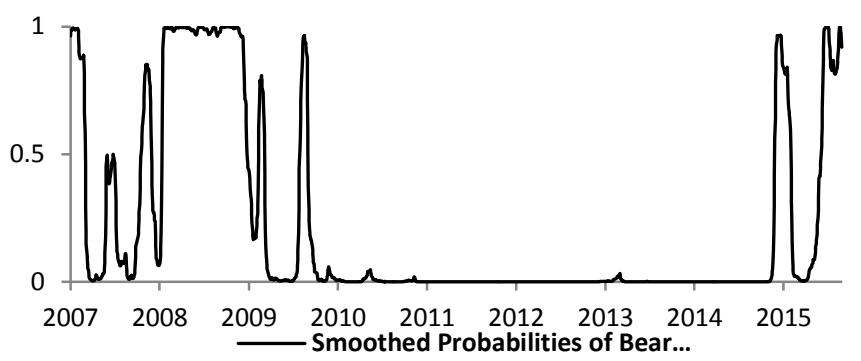

Figure 3. Smoothed probabilities for three market regimes

As seen from Table 2, we identify these three market types as follows: the regime with a medium mean and the lowest variance of returns $\left(\hat{\mu}_{\mathrm{S}_{\mathrm{t}}=1}=-0.0005, \widehat{\sigma}_{\mathrm{S}_{\mathrm{t}}=1}^{2}=0.0001\right)$ is designated as Medium market; the regime with the highest mean and a medium variance of returns $\left(\hat{\mu}_{\mathrm{S}_{\mathrm{t}}=2}=0.0033, \widehat{\sigma}_{\mathrm{S}_{\mathrm{t}}=2}^{2}=0.0002\right)$ is designated as Bull market; and the regime with the lowest mean and the highest variance of returns $\left(\hat{\mu}_{\mathrm{s}_{\mathrm{t}}=3}=-0.0029, \widehat{\sigma}_{\mathrm{S}_{\mathrm{t}}=3}^{2}=0.0007\right)$ is designated as Bear market. All the transition probabilities for the three regimes are high enough, which indicates a highly persistent market regime.

Table 2. The results of the markov switching model

\begin{tabular}{cccccc}
\hline$\mu_{\mathrm{S}_{\mathrm{t}}=1}$ & $\mu_{\mathrm{S}_{\mathrm{t}}=2}$ & $\mu_{\mathrm{S}_{\mathrm{t}}=3}$ & $\sigma_{\mathrm{S}_{\mathrm{t}}=1}^{2}$ & $\sigma_{\mathrm{S}_{\mathrm{t}}=2}^{2}$ & $\sigma_{\mathrm{S}_{\mathrm{t}}=3}^{2}$ \\
\hline$-0.0005^{*}$ & $0.0033^{* * *}$ & $-0.0029 * *$ & $0.0001 * * *$ & $0.0002 * * *$ & $0.0007 * * *$ \\
$(0.0003)$ & $(0.0008)$ & $(0.0014)$ & $(0.0000)$ & $(0.0000)$ & $(0.0001)$ \\
$\mathrm{P}^{11}$ & $\mathrm{P}^{22}$ & $\mathrm{P}^{33}$ & AIC & LogLik & \\
1 & 0.98 & 0.98 & -11430.1995 & 5731.0997 & \\
\hline
\end{tabular}

Note. The number in parentheses is stand error, *** and $* * *$ indicate $10 \%, 5 \%$ and $1 \%$ levels of significance, respectively.

Through the estimation of the Markov Switching model, we can obtain China's market regime divisions from 2007 to 2015, and the major market regimes are reported as Table 3. The main characteristics of the Bull market are the highest mean and a medium variance. Moreover, the stock returns increase dramatically within a short period, such as by $+109.14 \%$ in only 7 months. In contrast, the Bear market displays the lowest mean and the highest variance and accompanies a sharp decline in returns within a short period, such as $-66.24 \%$ in 11 months. 
Compared with the above two regimes, the Medium market's state is characterized as having a medium mean and the lowest variance. To clarify, it is shown to have a continuing lower volatility and return losses in terms of media width. Note that no accurate method existed to determine the market regime until now; our stock market division is not unique. Based on these results, we construct Bull, Medium and Bear dummy variables in our study.

Table 3. Major market regime division

\begin{tabular}{cccc}
\hline & Date & Duration & Average Daily Return \\
\hline Bull & $2007.03 .05-2007.10 .18$ & 7 months & 0.0041 \\
Bull & $2008.12 .29-2009.07 .30$ & 7 months & 0.0041 \\
Bull & $2009.09 .03-2010.01 .21$ & 4 months & 0.0006 \\
Bull & $2012.12 .18-2013.03 .11$ & 3 months & 0.0012 \\
Bull & $2015.02 .02-2015.06 .04$ & 4 months & 0.0037 \\
Medium & $2010.01 .22-2010.04 .21$ & 3 months & -0.0008 \\
Medium & $2010.06 .10-2010.09 .27$ & 3 months & -0.0006 \\
Medium & $2010.11 .18-2012.12 .17$ & 25 months & -0.0004 \\
Medium & $2013.03 .12-2014.11 .05$ & 20 months & -0.0001 \\
Bear & $2008.01 .11-2008.12 .26$ & 11 months & -0.0043 \\
Bear & $2015.06 .05-2015.08 .31$ & 3 months & -0.0063 \\
\hline
\end{tabular}

\subsection{The GJR-GARCH Results for Different Market Regime}

The empirical results of GJR-GARCH for the Shibor and the stock returns are reported in Table 4. First, the short-term interest rates always negatively affect the stock market returns in Bull and Medium market, whereas they have no significant effects in Bear market. The coefficients of $\beta_{1}$ indicate that the overnight, one-week, two-week, one-month and three-month Shibors significantly and negatively affect the stock returns in Medium market. As for Bull market, the coefficients of $\beta_{1}+\beta_{2}$ indicate that the two-week and one-month Shibors significantly and negatively affect the stock returns. However, in Bear markets, the coefficients of $\beta_{1}+\beta_{3}$ are sometimes negative and sometimes positive; also all of them are not significant, which indicates Shibors do not have a significant association with the stock returns. It seems the Shibor have biggest impacts in Bull market and smaller impact in Medium market and smallest in Bear market. In the view of statistic results, the coefficient of $\beta_{2}$ indicates that three month Shibor have stronger impact on stock return in Bull market than in Medium market; in addition, the significant positive coefficient of $\beta_{3}$ shows three month Shibor have stronger negative effect in Medium market than in Bear. These results indicate that a change in the Shibor asymmetrically affects the stock returns in China: the Shibor can negatively affect stock returns in Medium and Bull market, but it cannot affect stock returns in Bear market. These asymmetric effects may caused by irrational China's investor. In Bear market, the investor shows dramatic irrational and China's always fall suddenly and sharply, for example, China's stock market drop 30\% with one month in 2015. And the investors are easier to ignore the aggressive monetary policy in this kind of panic market. Thus, the easing monetary policy does not work well in Bear market. However, in Bull and Medium, investors become more rational and notice the change of monetary policy like short term interest rate fluctuate. Then, short term interest rate is easier to affect China's stock market in Bull and Medium market but not in Bear market.

Furthermore, the empirical results also show that different maturities of Shibor have different effects on stock returns. Only Shibor with relatively shorter maturities (less than three months) can significantly affect stock returns, whereas Shibor with relatively longer maturities cannot affect stock returns even in Mediun and Bull market. Hence, we conclude that Shibor with short maturities has larger effects on stock returns than Shibor of long maturities. The possible reason is that Shibor with short maturities is more likely to be determined by the money supply and demand, scilicet, it is more market-oriented and more volatile (as seen from Figure 2). Therefore, Shibor with short maturities reflects the authentic financial conditions of capital markets and has large effects on stock returns. However, Shibor with long maturities is more dominated by the official interest rates, and it may remain firm or change little for a relatively long period. Thus, Shibor with long maturities may not affect stock returns in short term.

Second, the short-term interest rates have a negative effect on market risk in Bull market, but a positive effect in Bear market. In Medium Market, all of the coefficients of $\lambda_{1}$ are very small and not significant, which indicates that the Shibor cannot affect the market risk. However, half of the coefficients of $\lambda_{1}+\lambda_{2}$ in Bull market are 
significantly negative, whereas most of the coefficients of $\lambda_{1}+\lambda_{3}$ in Bear market are significantly positive. These results indicate that a change in the Shibor also asymmetrically affects the stock risk in China: the Shibor can negatively affect stock risk in Bull market, positively affect stock risk in Bear market, but it cannot affect stock risk in Medium market. These findings show that the change of Shibor could reduce market risk in Bull market but enlarge market risk in Bear Market. The reasonable explanation may also be irrational investors and their behavior in Chinese stock market. With the huge fear in Bear market, the investor will react stronger and enlarge market risk (or volatility) when the short term interest rate changes. Whereas, in Bull market, the investor could rationally notice that interest rate against the economic wind direct is better for stock market and lead the change of Shibor reduce the market risk.

Table 4. Results of GJR-GARCH model

\begin{tabular}{|c|c|c|c|c|c|c|c|c|}
\hline & 1D & $1 \mathrm{~W}$ & $2 \mathrm{~W}$ & $1 \mathrm{M}$ & $3 \mathrm{M}$ & $6 \mathrm{M}$ & $9 \mathrm{M}$ & $1 \mathrm{Y}$ \\
\hline$\mu_{t}$ & $\begin{array}{l}-0.0005 \\
(-1.1852)\end{array}$ & $\begin{array}{l}-0.0005 \\
(-1.1947)\end{array}$ & $\begin{array}{c}-0.0005 \\
(-1.2016)\end{array}$ & $\begin{array}{c}-0.0005 \\
(-1.2931)\end{array}$ & $\begin{array}{l}-0.0005 \\
(-1.3213)\end{array}$ & $\begin{array}{l}-0.0005 \\
(1.1730)\end{array}$ & $\begin{array}{c}-0.0004 \\
(-0.6804)\end{array}$ & $\begin{array}{c}-0.0004 \\
(-0.6785)\end{array}$ \\
\hline$\beta_{1}$ & $\begin{array}{l}-0.0014 * * \\
(-2.0467)\end{array}$ & $\begin{array}{l}-0.0015^{*} \\
(-1.9150)\end{array}$ & $\begin{array}{c}-0.0018 * * \\
(-2.4472)\end{array}$ & $\begin{array}{l}-0.0024^{*} \\
(-1.8850)\end{array}$ & $\begin{array}{c}-0.0229 * * * \\
(-3.2404)\end{array}$ & $\begin{array}{c}-0.0256 \\
(-1.1647)\end{array}$ & $\begin{array}{c}-0.0394 \\
(-1.3134)\end{array}$ & $\begin{array}{c}-0.0379 \\
(-1.2249)\end{array}$ \\
\hline$\beta_{2}$ & $\begin{array}{c}0.0011 \\
(0.3927)\end{array}$ & $\begin{array}{c}-0.0009 \\
(-0.3197)\end{array}$ & $\begin{array}{c}-0.0028 \\
(-1.0287)\end{array}$ & $\begin{array}{c}-0.0089 * * * \\
(-2.6408)\end{array}$ & $\begin{array}{c}0.0201 \\
(0.5444)\end{array}$ & $\begin{array}{c}0.0240 \\
(0.4840)\end{array}$ & $\begin{array}{c}0.0225 \\
(0.4305)\end{array}$ & $\begin{array}{c}0.0046 \\
(0.0870)\end{array}$ \\
\hline$\beta_{3}$ & $\begin{array}{c}-0.0030 \\
(-0.7674)\end{array}$ & $\begin{array}{c}-0.0027 \\
(-0.9156)\end{array}$ & $\begin{array}{c}-0.0010 \\
(-0.5351)\end{array}$ & $\begin{array}{c}-0.0016 \\
(-0.3246)\end{array}$ & $\begin{array}{l}0.0479^{*} \\
(1.7487)\end{array}$ & $\begin{array}{c}0.0346 \\
(0.7888)\end{array}$ & $\begin{array}{c}0.0394 \\
(0.5389)\end{array}$ & $\begin{array}{c}0.0384 \\
(0.5001)\end{array}$ \\
\hline$\beta_{1}+\beta_{2}$ & $\begin{array}{l}-0.0003 \\
(0.0094)\end{array}$ & $\begin{array}{l}-0.0022 \\
(0.7304\end{array}$ & $\begin{array}{l}-0.0046^{*} \\
(3.1472)\end{array}$ & $\begin{array}{c}-0.0114 * * * \\
(13.2686)\end{array}$ & $\begin{array}{l}-0.0028 \\
(0.0058)\end{array}$ & $\begin{array}{l}-0.0016 \\
(0.0012)\end{array}$ & $\begin{array}{l}-0.0017 \\
(0.1553)\end{array}$ & $\begin{array}{l}-0.0335 \\
(0.6191)\end{array}$ \\
\hline$\beta_{1}+\beta_{3}$ & $\begin{array}{l}-0.0044 \\
(1.3106)\end{array}$ & $\begin{array}{l}-0.0040 \\
(2.1322)\end{array}$ & $\begin{array}{l}-0.0029 \\
(2.5426)\end{array}$ & $\begin{array}{l}-0.0041 \\
(0.7010)\end{array}$ & $\begin{array}{c}0.0250 \\
(0.8932)\end{array}$ & $\begin{array}{c}0.0091 \\
(0.0525)\end{array}$ & $\begin{array}{l}-0.0000 \\
(0.0000)\end{array}$ & $\begin{array}{l}-0.0004 \\
(0.0000)\end{array}$ \\
\hline$\beta_{2}-\beta_{3}$ & $\begin{array}{c}0.0042 \\
(0.7505)\end{array}$ & $\begin{array}{c}0.0017 \\
(0.1997)\end{array}$ & $\begin{array}{l}-0.0017 \\
(0.3023)\end{array}$ & $\begin{array}{l}-0.0073 \\
(1.5970)\end{array}$ & $\begin{array}{l}-0.0278 \\
(0.3816)\end{array}$ & $\begin{array}{l}-0.0106 \\
(0.0315)\end{array}$ & $\begin{array}{l}-0.0169 \\
(0.0452)\end{array}$ & $\begin{array}{l}-0.0338 \\
(0.1700)\end{array}$ \\
\hline$\beta_{4}$ & $\begin{array}{c}1.8628 \\
(1.3263) \\
\end{array}$ & $\begin{array}{c}1.8159 \\
(1.2960) \\
\end{array}$ & $\begin{array}{c}1.9288 \\
(1.3724) \\
\end{array}$ & $\begin{array}{c}2.1091 \\
(1.4883) \\
\end{array}$ & $\begin{array}{c}2.1209 \\
(1.4965) \\
\end{array}$ & $\begin{array}{c}1.9699 \\
(1.3797) \\
\end{array}$ & $\begin{array}{c}1.8141 \\
(1.2708) \\
\end{array}$ & $\begin{array}{c}1.7168 \\
(1.1986) \\
\end{array}$ \\
\hline$\omega$ & $\begin{array}{c}0.0000 \\
(0.8044)\end{array}$ & $\begin{array}{c}0.0000 \\
(0.5169)\end{array}$ & $\begin{array}{c}0.0000 \\
(0.9050)\end{array}$ & $\begin{array}{c}0.0000 \\
(0.6113)\end{array}$ & $\begin{array}{c}0.0000 \\
(0.3524)\end{array}$ & $\begin{array}{c}0.0000 \\
(0.1113)\end{array}$ & $\begin{array}{l}0.0000 \\
(0.207)\end{array}$ & $\begin{array}{c}0.0000 \\
(0.2918)\end{array}$ \\
\hline$\eta$ & $\begin{array}{c}0.0359 * * * \\
(4.4435)\end{array}$ & $\begin{array}{c}0.0315 * * * \\
(4.2349\end{array}$ & $\begin{array}{c}0.0353 * * * \\
(4.2910)\end{array}$ & $\begin{array}{c}0.0317 * * * \\
(4.3096)\end{array}$ & $\begin{array}{c}0.0304 * * * \\
(4.1765)\end{array}$ & $\begin{array}{c}0.0282 * * * \\
(4.0483)\end{array}$ & $\begin{array}{c}0.0310 * * * \\
(4.2713)\end{array}$ & $\begin{array}{c}0.0334 * * * \\
(4.4615)\end{array}$ \\
\hline$\gamma$ & $\begin{array}{c}0.0002 \\
(0.0210)\end{array}$ & $\begin{array}{l}-0.0007 \\
(-0.0669\end{array}$ & $\begin{array}{c}0.0028 \\
(0.2623)\end{array}$ & $\begin{array}{c}0.0006 \\
(0.0613)\end{array}$ & $\begin{array}{c}-0.0012 \\
(-0.1292)\end{array}$ & $\begin{array}{c}-0.0002 \\
(-0.0213)\end{array}$ & $\begin{array}{c}-0.0012 \\
(-0.1294)\end{array}$ & $\begin{array}{c}-0.0019 * * * * \\
(-0.1954)\end{array}$ \\
\hline$\theta$ & $\begin{array}{l}0.9659 * * * \\
(153.4759)\end{array}$ & $\begin{array}{l}0.9707 * * * \\
(164.3470)\end{array}$ & $\begin{array}{l}0.9650^{* * * *} \\
(152.5396)\end{array}$ & $\begin{array}{l}0.9696^{* * * *} \\
(163.5274)\end{array}$ & $\begin{array}{l}0.9722 * * * \\
(168.2928)\end{array}$ & $\begin{array}{l}0.9742 * * * \\
(177.7699)\end{array}$ & $\begin{array}{l}0.9722 * * * \\
(170.9756)\end{array}$ & $\begin{array}{l}0.9704 * * * \\
(163.6372)\end{array}$ \\
\hline$\lambda_{1}$ & $\begin{array}{c}0.0000 \\
(0.4586)\end{array}$ & $\begin{array}{c}0.0000 \\
(0.6288)\end{array}$ & $\begin{array}{c}0.0000 \\
(0.0777)\end{array}$ & $\begin{array}{c}0.0000 \\
(1.2166)\end{array}$ & $\begin{array}{c}0.0000 \\
(0.6878)\end{array}$ & $\begin{array}{c}0.0000 \\
(0.0560)\end{array}$ & $\begin{array}{c}-0.0000 \\
(-0.0891)\end{array}$ & $\begin{array}{c}-0.0000 \\
(-0.2114)\end{array}$ \\
\hline$\lambda_{2}$ & $\begin{array}{c}0.0000 \\
(0.0163)\end{array}$ & $\begin{array}{l}-0.0000 \\
(-0.1291\end{array}$ & $\begin{array}{c}0.0000 \\
(0.7076)\end{array}$ & $\begin{array}{c}-0.0000 \\
(-0.4098)\end{array}$ & $\begin{array}{c}-0.0002 * * \\
(-1.9973)\end{array}$ & $\begin{array}{c}-0.0003 * * \\
(-2.5034)\end{array}$ & $\begin{array}{c}-0.0003 * * \\
(-2.3123)\end{array}$ & $\begin{array}{l}-0.0002 * \\
(-1.9082)\end{array}$ \\
\hline$\lambda_{3}$ & $\begin{array}{c}0.0002 \\
(1.0210) \\
\end{array}$ & $\begin{array}{l}0.0002 * * \\
(2.1467)\end{array}$ & $\begin{array}{c}0.0001 \\
(1.5199) \\
\end{array}$ & $\begin{array}{c}0.0003^{* *} \\
(2.5658) \\
\end{array}$ & $\begin{array}{c}0.0003 * * \\
(2.5288) \\
\end{array}$ & $\begin{array}{c}0.0003^{* *} \\
(2.4649) \\
\end{array}$ & $\begin{array}{c}0.0003 * * \\
(2.0522) \\
\end{array}$ & $\begin{array}{l}0.0003 * \\
(1.7367) \\
\end{array}$ \\
\hline$\lambda_{1}+\lambda_{2}$ & $\begin{array}{c}0.0000 \\
(0.0101)\end{array}$ & $\begin{array}{c}0.0000 \\
(0.0001)\end{array}$ & $\begin{array}{c}0.0000 \\
(0.5476)\end{array}$ & $\begin{array}{l}-0.0000 \\
(0.0163)\end{array}$ & $\begin{array}{l}-0.0002 * \\
(3.6917)\end{array}$ & $\begin{array}{c}-0.0003^{* * *} * \\
(6.8823)\end{array}$ & $\begin{array}{c}-0.0003 * * \\
(6.0953)\end{array}$ & $\begin{array}{c}-0.0003 * * \\
(4.2728)\end{array}$ \\
\hline$\lambda_{1}+\lambda_{3}$ & $\begin{array}{c}0.0002 \\
(1.0904)\end{array}$ & $\begin{array}{c}0.0002 * * \\
(4.8539)\end{array}$ & $\begin{array}{c}0.0001 \\
(2.4147)\end{array}$ & $\begin{array}{c}0.0003^{* * * *} \\
(7.1097)\end{array}$ & $\begin{array}{c}0.0003^{* * *} * \\
(7.1318)\end{array}$ & $\begin{array}{c}0.0003^{* *} \\
(6.4632)\end{array}$ & $\begin{array}{c}0.0003 * * \\
(4.3525)\end{array}$ & $\begin{array}{l}0.0003 * \\
(3.0238)\end{array}$ \\
\hline$\lambda_{2}-\lambda_{3}=0$ & $\begin{array}{l}-0.0002 \\
(0.9823) \\
\end{array}$ & $\begin{array}{c}-0.0002 * * \\
(4.6774) \\
\end{array}$ & $\begin{array}{l}-0.0000 \\
(1.0921) \\
\end{array}$ & $\begin{array}{c}-0.0003 * * * \\
(6.9345) \\
\end{array}$ & $\begin{array}{c}-0.0005^{* * *} * \\
(9.3439) \\
\end{array}$ & $\begin{array}{c}-0.0006^{* * * *} \\
(10.6884) \\
\end{array}$ & $\begin{array}{c}-0.0006^{* * * *} \\
(7.8065) \\
\end{array}$ & $\begin{array}{c}-0.0006^{* *} * \\
(5.3774)\end{array}$ \\
\hline $\begin{array}{l}\text { T-Dist DOF } \\
\text { LogLik }\end{array}$ & $\begin{array}{c}4.7351 \\
5725.554\end{array}$ & $\begin{array}{c}4.6955 \\
5728.743\end{array}$ & $\begin{array}{c}4.7473 \\
5727.982\end{array}$ & $\begin{array}{c}4.8475 \\
5732.210\end{array}$ & $\begin{array}{c}4.8081 \\
5732.030\end{array}$ & $\begin{array}{c}4.8734 \\
5727.571\end{array}$ & $\begin{array}{c}4.8457 \\
5727.049\end{array}$ & $\begin{array}{c}4.8349 \\
5726.018\end{array}$ \\
\hline
\end{tabular}

Note. The number in parentheses is z-statistic or F-statistic, *** and *** indicate $10 \%, 5 \%$ and $1 \%$ levels of significance, respectively.

\subsection{Robustness Check}

The main results of this paper is that short-term interest rates cannot affect stock returns in Bear market, but can significantly and negatively affect stock returns in Medium and Bull markets. Additionally, Shibor with short maturities have larger effects on stock returns than Shibor with long maturities. On the other hand, the short-term interest rates can negatively affect stock risk in Bull market, positively affect stock risk in Bear market, but it 
cannot affect stock risk in Medium market. All the above findings are based on the GJR-GARCH model which we use because Engle and $\mathrm{Ng}$ (1993) indicates the GJR-GARCH is a better model to measuring the impacts of news on volatility. However, the classical model to test the impacts of short term interest rate on stock market is the EGARCH model proved by Henry (2009). Thus, we follow Henry (2009) to adopt the following EGARCH model to test the robustness of these results.

$$
\begin{gathered}
R_{t}=\mu_{t}+\beta_{1} \Delta r_{n, t-1}+\beta_{2} x_{\text {bull }} \Delta r_{n, t-1}+\beta_{3} x_{\text {bear }} \Delta r_{n, t-1}+\beta_{4} \sigma_{t}^{2}+\xi_{t} \\
\xi_{t} \sim i . i . d . t\left(0, \sigma_{S_{t}}^{2}, K_{S_{t}}\right) \\
\log \left(\sigma_{t}^{2}\right)=\omega+\alpha \frac{\left|\xi_{t-1}\right|}{\sigma_{t-1}}+\delta \frac{\xi_{t-1}}{\sigma_{t-1}}+\rho \log \left(\sigma_{t-1}\right)+\lambda_{1} \Delta r_{n, t-1}+\lambda_{2} x_{\text {bull }} \Delta r_{n, t-1}+\lambda_{3} x_{\text {bear }} \Delta r_{n, t-1}
\end{gathered}
$$

Table 5 reports the empirical results of EGARCH model. As shown from Table 5, we obtain the very similar

\begin{tabular}{|c|c|c|c|c|c|c|c|c|}
\hline & 1D & $1 \mathrm{~W}$ & $2 \mathrm{~W}$ & $1 \mathrm{M}$ & $3 \mathrm{M}$ & $6 \mathrm{M}$ & $9 \mathrm{M}$ & $1 \mathrm{Y}$ \\
\hline$\mu_{t}$ & $\begin{array}{c}-0.0005 \\
(-1.1276)\end{array}$ & $\begin{array}{c}-0.0005 \\
(-1.1300)\end{array}$ & $\begin{array}{c}-0.0005 \\
(-1.2238)\end{array}$ & $\begin{array}{c}-0.0005 \\
(-1.2390)\end{array}$ & $\begin{array}{c}-0.0005 \\
(-1.3425)\end{array}$ & $\begin{array}{c}-0.0004 \\
(-1.0993)\end{array}$ & $\begin{array}{c}-0.0004 \\
(-1.0259)\end{array}$ & $\begin{array}{c}-0.0004 \\
(-0.9357)\end{array}$ \\
\hline$\beta_{1}$ & $\begin{array}{l}-0.0014^{*} \\
(-1.9410)\end{array}$ & $\begin{array}{c}-0.0015 * * \\
(-2.0156)\end{array}$ & $\begin{array}{c}-0.0019 * * \\
(-2.5416)\end{array}$ & $\begin{array}{c}-0.0026^{* *} \\
(-1.9969)\end{array}$ & $\begin{array}{c}-0.0225 * * * \\
(-3.3477)\end{array}$ & $\begin{array}{c}-0.0259 \\
(-1.1927)\end{array}$ & $\begin{array}{c}-0.0388 \\
(-1.3192)\end{array}$ & $\begin{array}{c}-0.0383 \\
(-1.2546)\end{array}$ \\
\hline$\beta_{2}$ & $\begin{array}{c}0.0014 \\
(0.5632)\end{array}$ & $\begin{array}{c}-0.0002 \\
(-0.0650)\end{array}$ & $\begin{array}{c}-0.0023 \\
(-0.8932)\end{array}$ & $\begin{array}{c}-0.0084 * * \\
(-2.5721)\end{array}$ & $\begin{array}{c}0.0201 \\
(0.5390)\end{array}$ & $\begin{array}{c}0.0264 \\
(0.5320)\end{array}$ & $\begin{array}{c}0.0270 \\
(0.5126)\end{array}$ & $\begin{array}{c}0.0110 \\
(0.2079)\end{array}$ \\
\hline$\beta_{3}$ & $\begin{array}{c}-0.0031 \\
(-0.7129)\end{array}$ & $\begin{array}{c}-0.0023 \\
(-0.8477)\end{array}$ & $\begin{array}{c}-0.0010 \\
(-0.5051)\end{array}$ & $\begin{array}{c}-0.0014 \\
(-0.2544)\end{array}$ & $\begin{array}{l}0.0464 * \\
(1.7890)\end{array}$ & $\begin{array}{c}0.0353 \\
(0.8188)\end{array}$ & $\begin{array}{c}0.0389 \\
(0.5417)\end{array}$ & $\begin{array}{c}0.0387 \\
(0.5078)\end{array}$ \\
\hline$\beta_{1}+\beta_{2}$ & $\begin{array}{c}0.0001 \\
(0.0005)\end{array}$ & $\begin{array}{l}-0.0016 \\
(0.4523)\end{array}$ & $\begin{array}{l}-0.0042 * \\
(2.8280)\end{array}$ & $\begin{array}{c}-0.0110^{* * *} \\
(13.2538)\end{array}$ & $\begin{array}{l}-0.0024 \\
(0.0044)\end{array}$ & $\begin{array}{c}0.0005 \\
(0.0001)\end{array}$ & $\begin{array}{l}-0.0118 \\
(0.0728)\end{array}$ & $\begin{array}{l}-0.0273 \\
(0.3954)\end{array}$ \\
\hline$\beta_{1}+\beta_{3}$ & $\begin{array}{l}-0.0045 \\
(1.0835)\end{array}$ & $\begin{array}{l}-0.0038 \\
(2.0406)\end{array}$ & $\begin{array}{l}-0.0028 \\
(2.5681)\end{array}$ & $\begin{array}{l}-0.0040 \\
(0.5422)\end{array}$ & $\begin{array}{c}0.0238 \\
(0.9071)\end{array}$ & $\begin{array}{c}0.0094 \\
(0.0641)\end{array}$ & $\begin{array}{c}0.0001 \\
(0.0000)\end{array}$ & $\begin{array}{c}0.0004 \\
(0.0000)\end{array}$ \\
\hline$\beta_{2}+\beta_{3}$ & $\begin{array}{c}0.0045 \\
(0.8309)\end{array}$ & $\begin{array}{c}0.0022 \\
(0.3682)\end{array}$ & $\begin{array}{l}-0.0013 \\
(0.1946)\end{array}$ & $\begin{array}{l}-0.0070 \\
(1.3034)\end{array}$ & $\begin{array}{l}-0.0263 \\
(0.3494)\end{array}$ & $\begin{array}{l}-0.0090 \\
(0.0234)\end{array}$ & $\begin{array}{l}-0.0119 \\
(0.0226)\end{array}$ & $\begin{array}{l}-0.0277 \\
(0.1130)\end{array}$ \\
\hline$\beta_{4}$ & $\begin{array}{c}1.7831 \\
(1.2859)\end{array}$ & $\begin{array}{c}1.7244 \\
(1.2519)\end{array}$ & $\begin{array}{c}1.8984 \\
(1.3784)\end{array}$ & $\begin{array}{c}1.9613 \\
(1.4201)\end{array}$ & $\begin{array}{c}2.0604 \\
(1.4884)\end{array}$ & $\begin{array}{c}1.8614 \\
(1.3273)\end{array}$ & $\begin{array}{c}1.7504 \\
(1.2465)\end{array}$ & $\begin{array}{c}1.6698 \\
(1.1832) \\
\end{array}$ \\
\hline$\omega$ & $\begin{array}{c}-0.0876 * * * \\
(-3.9765)\end{array}$ & $\begin{array}{c}-0.0858 * * * \\
(-3.9149)\end{array}$ & $\begin{array}{c}-0.0873 * * * \\
(-3.8727)\end{array}$ & $\begin{array}{c}-0.0807 * * * \\
(-3.7817)\end{array}$ & $\begin{array}{c}-0.0779 * * * \\
(-3.7656)\end{array}$ & $\begin{array}{c}-0.0823 * * * \\
(-3.8784)\end{array}$ & $\begin{array}{c}-0.0837 * * * \\
(-3.9138)\end{array}$ & $\begin{array}{c}-0.0839 * * * \\
(-3.8799)\end{array}$ \\
\hline$\alpha$ & $\begin{array}{c}0.0970 * * * \\
(6.1337)\end{array}$ & $\begin{array}{c}0.0956^{* * *} \\
(5.9663)\end{array}$ & $\begin{array}{c}0.0979 * * * \\
(6.1515)\end{array}$ & $\begin{array}{c}0.0917 \text { *** } \\
(5.9537)\end{array}$ & $\begin{array}{c}0.0901^{* * *} \\
(5.8723)\end{array}$ & $\begin{array}{c}0.0917 * * * \\
(5.8918)\end{array}$ & $\begin{array}{c}0.0931 * * * \\
(5.9456)\end{array}$ & $\begin{array}{c}0.0943 * * * \\
(5.9903)\end{array}$ \\
\hline$\delta$ & $\begin{array}{c}0.0015 \\
(0.1581)\end{array}$ & $\begin{array}{c}0.0014 \\
(0.1502)\end{array}$ & $\begin{array}{c}-0.0018 \\
(-0.1867)\end{array}$ & $\begin{array}{c}-0.0002 \\
(-0.0229)\end{array}$ & $\begin{array}{c}0.0003 \\
(0.0294)\end{array}$ & $\begin{array}{c}-0.0003 \\
(-0.0338)\end{array}$ & $\begin{array}{c}0.0004 \\
(0.0464)\end{array}$ & $\begin{array}{c}0.0013 \\
(0.1373)\end{array}$ \\
\hline$\rho$ & $\begin{array}{l}0.9978^{* * * *} \\
(503.8768) \\
\end{array}$ & $\begin{array}{l}0.9979 * * * \\
(513.3027) \\
\end{array}$ & $\begin{array}{l}0.9979 * * * \\
(490.8392) \\
\end{array}$ & $\begin{array}{l}0.9982^{* * *} \\
(528.7357) \\
\end{array}$ & $\begin{array}{l}0.9984^{* * *} * \\
(545.7230)\end{array}$ & $\begin{array}{l}0.9980 * * * \\
(527.1523) \\
\end{array}$ & $\begin{array}{l}0.9979 * * * \\
(519.2074) \\
\end{array}$ & $\begin{array}{l}0.9980 * * * \\
(512.2843) \\
\end{array}$ \\
\hline$\lambda_{1}$ & $\begin{array}{c}0.0322 \\
(0.5781)\end{array}$ & $\begin{array}{c}0.0338 \\
(0.6323)\end{array}$ & $\begin{array}{c}-0.0196 \\
(-0.3516)\end{array}$ & $\begin{array}{c}0.0563 \\
(0.9788)\end{array}$ & $\begin{array}{c}0.0511 \\
(0.3351)\end{array}$ & $\begin{array}{c}-0.0860 \\
(-0.3045)\end{array}$ & $\begin{array}{c}-0.1711 \\
(-0.5493)\end{array}$ & $\begin{array}{c}-0.2158 \\
(-0.6575)\end{array}$ \\
\hline$\lambda_{2}$ & $\begin{array}{c}-0.1397 \\
(-0.9151)\end{array}$ & $\begin{array}{c}-0.1682 \\
(-1.4894)\end{array}$ & $\begin{array}{c}0.0549 \\
(0.5350)\end{array}$ & $\begin{array}{c}-0.1479 \\
(-1.2257)\end{array}$ & $\begin{array}{c}-0.4437 \\
(-1.5984)\end{array}$ & $\begin{array}{c}-0.5760 \\
(-1.4226)\end{array}$ & $\begin{array}{c}-0.5330 \\
(-1.1985)\end{array}$ & $\begin{array}{c}-0.4297 \\
(-0.9422)\end{array}$ \\
\hline$\lambda_{3}$ & $\begin{array}{c}0.2046 \\
(0.9485)\end{array}$ & $\begin{array}{c}0.2143 \\
(1.5155)\end{array}$ & $\begin{array}{c}0.2403 \\
(1.9157)\end{array}$ & $\begin{array}{l}0.3555^{*} \\
(1.8698)\end{array}$ & $\begin{array}{c}0.4168 \\
(1.4640)\end{array}$ & $\begin{array}{c}0.5035 \\
(1.2918)\end{array}$ & $\begin{array}{c}0.5608 \\
(1.2961)\end{array}$ & $\begin{array}{c}0.5958 \\
(1.2851)\end{array}$ \\
\hline$\lambda_{1}+\lambda_{2}$ & $\begin{array}{l}-0.1075 \\
(0.5733)\end{array}$ & $\begin{array}{l}-0.1344 \\
(1.8349)\end{array}$ & $\begin{array}{c}0.0353 \\
(0.1644)\end{array}$ & $\begin{array}{l}-0.0916 \\
(0.7364)\end{array}$ & $\begin{array}{l}-0.3926^{*} \\
(3.0361)\end{array}$ & $\begin{array}{c}-0.6621 * * \\
(5.7532)\end{array}$ & $\begin{array}{c}-0.7040^{* *} \\
(5.4273)\end{array}$ & $\begin{array}{c}-0.6455^{* *} \\
(4.4554)\end{array}$ \\
\hline$\lambda_{1}+\lambda_{3}$ & $\begin{array}{c}0.2367 \\
(1.2906)\end{array}$ & $\begin{array}{l}0.2481 * \\
(3.6136)\end{array}$ & $\begin{array}{c}0.2206^{* *} \\
(3.8857)\end{array}$ & $\begin{array}{c}0.4119^{* *} \\
(5.2238)\end{array}$ & $\begin{array}{l}0.4679 * \\
(3.8382)\end{array}$ & $\begin{array}{c}0.4175 \\
(2.4313)\end{array}$ & $\begin{array}{c}0.3897 \\
(1.6959)\end{array}$ & $\begin{array}{c}0.3800 \\
(1.3786)\end{array}$ \\
\hline$\lambda_{2}-\lambda_{3}$ & $\begin{array}{l}-0.3443 \\
(1.9275) \\
\end{array}$ & $\begin{array}{c}-0.3825 * * \\
(6.1872) \\
\end{array}$ & $\begin{array}{l}-0.1853 \\
(2.2647) \\
\end{array}$ & $\begin{array}{c}-0.5034 * * \\
(6.2257) \\
\end{array}$ & $\begin{array}{c}-0.8605^{* *} \\
(6.6140) \\
\end{array}$ & $\begin{array}{c}-1.0796 * * * \\
(6.9353) \\
\end{array}$ & $\begin{array}{c}-1.0937 * * \\
(5.5432) \\
\end{array}$ & $\begin{array}{c}-1.0255^{* *} \\
(4.5606) \\
\end{array}$ \\
\hline $\begin{array}{c}\text { T-Dist DOF } \\
\text { LogLik }\end{array}$ & $\begin{array}{c}4.7664 \\
5724.645\end{array}$ & $\begin{array}{c}4.7289 \\
5727.599\end{array}$ & $\begin{array}{c}4.7522 \\
5727.884\end{array}$ & $\begin{array}{c}4.7949 \\
5730.531\end{array}$ & $\begin{array}{c}4.7765 \\
5729.085\end{array}$ & $\begin{array}{c}4.8676 \\
5724.574\end{array}$ & $\begin{array}{c}4.8496 \\
5724.690\end{array}$ & $\begin{array}{c}4.8537 \\
5724.295\end{array}$ \\
\hline
\end{tabular}
results. Therefore, it is clear that the robustness of the supports the main results of this paper.

Table 5. Results of EGARCH model

Note. The number in parentheses is z-statistic or F-statistic, *** and *** indicate $10 \%, 5 \%$ and $1 \%$ levels of significance, respectively. 


\section{Conclusions}

This paper shows that China's stock market structure should be divided into three regimes: Medium market (with a medium mean and the lowest variance), Bull market (with the highest mean and a medium variance), and Bear market (with the lowest mean and the highest variance). Then, we apply GJR-GARCH model to show the asymmetric reactions of China's stock market to short-term interest rates. We find that short-term interest rates cannot affect the stock returns in Bear markets, whereas short-term interest rates have a significant and negative effect on stock returns in Medium and Bull market. In additional, Shibor with short maturities have larger effects on stock returns than Shibor with long maturities. On the other hand, the short-term interest rates can negatively affect stock risk in Bull market, positively affect stock risk in Bear market, but it cannot affect stock risk in Medium market.

From our findings, we know that China's stock market structure does not exhibit the traditional market character of long-term bull markets (positive returns) and short-term bear markets (negative returns); instead, this stock market has long-term medium market regimes and bear market regimes (native returns). Therefore, the investing strategy of "buy and hold or buy the ETF of the market index" may not be a good choice in China, since China's market portfolio cannot always guarantee a benefit to the investor in the long run. Second, because of the asymmetric relationship between the short-term interest and the stock market, global investors should predict China's market through observing the short-term interest rate trends by different logic in different market regime. Furthermore, it is clear that the investment logic in China is different from the investment logic in other countries, and if the global investors who invest in China use developed countries' wisdom, they will suffer huge losses. That may be why many winners (such as Anthony Bolton) in developed countries lose in China.

Our future research will focus on how the stock market reacts to monetary policy changes in different economic cycles and how firms with different financial constraints react to the monetary policy. We hope our research will describe a full picture of the relationship between the monetary policy and the stock market in China.

\section{Acknowledgments}

Supported by the National Social Science Foundation of China (14ZDA025, 12AZD059), the National Natural Science Foundation of China (71402005), the Fundamental Research Funds for the Central Universities (310400086) and the Social Science Foundation of Beijing (15JGC155).

\section{References}

Basistha, A., \& Kurov A. (2008). Macroeconomic cycles and the stock market's reaction to monetary policy. Journal of Banking \& Finance, 32, 2606-2616. http://dx.doi.org/10.1016/j.jbankfin.2008.05.012

Bollerslev, T. (1986). Generalized Autoregressive Conditional Heteroskedasticity. Journal of Econometrics, 31, 307-327. http://dx.doi.org/10.1016/0304-4076(86)90063-1

Campbell, J. Y., \& Ammer, J. (1993). What moves the stock and bond markets? A variance decomposition for long-term asset returns. Journal of Economics and Business, 55, 585-607. http://dx.doi.org/10.1111/j.1540-6261.1993.tb04700.x

Campbell, J. Y., \& Shiller, R. J. (1988). The dividend-price ratio and expectations of future dividends and discount factors. Review of Financial Studies, 1, 195-228. http://dx.doi.org/10.1093/rfs/1.3.195

Chen, S. S. (2007). Does monetary policy have asymmetric effects on stock returns? Journal of Money, Credit \& Banking, 39, 667-688. http://dx.doi.org/10.1111/j.0022-2879.2007.00040.x

Dickey, D. A., \& Fuller, W. A. (1979). Distribution of the estimators for autoregressive time series with a unit root. Journal of the American Statistical Society, 75, 427-431. http://dx.doi.org/10.2307/2286348

Engle, R. F. (1982). Autoregressive conditional heteroskedasticity with estimates of the variance of United Kingdom inflation. Econometrica, 50, 987-1008. http://dx.doi.org/10.2307/1912773

Engle, R. F., \& Ng, V. K. (1993). Measuring and testing the impact of news on volatility. Journal of Finance, 48, 1749-1778. http://dx.doi.org/10.1111/j.1540-6261.1993.tb05127.x

Fan, L., Yu, Y., \& Zhang, C. (2011). An empirical evaluation of china's monetary policies. Journal of Macroeconomics, 33, 358-371. http://dx.doi.org/ 10.1016/j.jmacro.2010.11.003

Gagnon, M. H., \& Gimet, C. (2013). The impacts of standard monetary and budgetary policies on liquidity and financial markets: International evidence from the credit freeze crisis. Journal of Banking \& Finance, 37, 4599-4614. http://dx.doi.org/10.1016/j.jbankfin.2013.04.003

Glosten, L. R., Jagannathan, R., \& Runkle, D. E. (1989). On the relation between the expected value and the 
volatility of the nominal excess return on stocks, Journal of Finance, 48, 1779-1801. http://dx.doi.org/10.2307/2329067

Gospondinov, N., \& Jamali, I. (2015). The response of stock market volatility to futures-based measures of monetary policy shocks. International Review of Economics \& Finance, 37, 42-54. http://dx.doi.org/10.1016/j.iref.2014.11.001

Hamilton, J. D. (1989). A new approach to the economic analysis of non-stationary time series and the business cycle. Econometrica, 57, 357-384. http://dx.doi.org/10.2307/1912559

Henry, O. T. (2009). Regime switching in the relationship between equity returns and short-term interest rates in the UK. Journal of Banking \& Finance, 33, 405-414. http://dx.doi.org/10.1016/j.jbankfin.2008.08.001

Kurov, A. (2010). Investor sentiment and the stock market's reaction to monetary policy. Journal of Banking \& Finance, 34, 13-9149.

Li, J. F. (2015). The asymmetric effects of investor sentiment and monetary policy on stock prices. Applied Economics, 47, 2514-2522. http://dx.doi.org/10.1016/j.jbankfin.2009.07.010

Liu, S. L., Chen, G. F., \& Hamori, S. (2014). Empirical research on monetary policy, asset prices and inflation: An analysis based on provincial panel data in China. Applied Economics, 46, 4190-4204. http://dx.doi.org/10.1080/00036846.2014.952892

Lv, X. (2012). Asymmetric effects of monetary policy shocks on shock markets: An empirical test for China. Journal of Chinese Economics Studies, 9, 1-19.

Lv, X., Dong, W. J., \& Fang, F. (2015). The asymmetric effects of official interest rate changes on China's stock market during different market regimes. Emerging Markets Finance \& Trade, 51, 826-841. http://dx.doi.org/10.1080/1540496X.2015.1047305

Phillips, P. C. B., \& Perron, P. (1988). Testing for a unit root in time series regressions. Biometrika, 75, 335-346. http://dx.doi.org/10.1093/biomet/75.2.335

Rigobon, R., \& Sack, B. (2003). Measuring the reaction of monetary policy to the stock market. Quarterly Journal of Economics, 118, 639-666. http://dx.doi.org/10.1162/003355303321675473

Thorbecke, W. (1997). On stock market returns and monetary policy. Journal of Finance, 52, 635-654. http://dx.doi.org/10.1111/j.1540-6261.1997.tb04816.x

Yao. S. J., Luo, D., \& Loh, L. X. (2013). On China's monetary policy and asset prices. Applied Financial Economics, 23, 377-392. http://dx.doi.org/10.1080/09603107.2012.725929

Zakoian, J. M. (1994) Threshold heteroskedastic models. Journal of Economic Dynamics \& Control, 18, 931-955. http://dx.doi.org/10.1016/0165-1889(94)90039-6

\section{Copyrights}

Copyright for this article is retained by the author(s), with first publication rights granted to the journal.

This is an open-access article distributed under the terms and conditions of the Creative Commons Attribution license (http://creativecommons.org/licenses/by/3.0/). 